\title{
CHARACTERISTICS OF MALIGNANT THYROID TUMORS: A RETROSPECTIVE STUDY ON 320 PATIENTS
}

\author{
Ivan Abičić2, Tin Prpić , Vjeran Bogović², Stjepan Grga Milanković2, Hrvoje Mihalj, ${ }^{1,2}$,

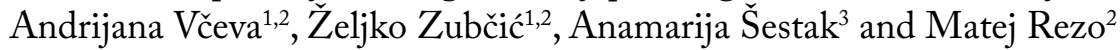 \\ ${ }^{1}$ Department of Otorhinolaryngology and Maxillofacial Surgery, Osijek Medical Faculty, \\ J.J. Strossmayer Osijek University, J. Huttlera 4, Osijek, Croatia; \\ ${ }^{2}$ Department of Otorhinolaryngology and Head and Neck Surgery, \\ Osijek Clinical Hospital Centre, J. Huttlera 4, Osijek, Croatia; \\ ${ }^{3}$ Department of Otorhinolaryngology, Vukovar General Hospital, Županijska ul. 35, Vukovar, Croatia
}

SUMMARY - Papillary thyroid cancer accounts for $80-85 \%$ of diagnosed thyroid cancers, while follicular, medullary, and anaplastic cancers are diagnosed significantly less frequently. This study aimed to show the characteristics of malignant thyroid tumors. In this retrospective study, we analyzed data from 320 patients who underwent thyroid surgery from January 2018 to December 2019. We recorded and statistically analyzed basic demographic data, data of the cytological and pathohistological findings, and tumor characteristics (size, multifocality, extrathyroidal and lymphovascular invasion). Thyroid cancer was diagnosed in 95 patients. The incidence of thyroid cancer was higher in women than in men, but without a significant difference $(\mathrm{p}=0.46)$. There was a significant difference between preoperative cytological findings and definitive pathohistological diagnosis $(\mathrm{p}=0.001)$. There was no significant difference between genders in tumor size, extrathyroidal and lymphovascular invasion, and multifocality. There were significantly more thyroid cancers with a lymphovascular invasion that were less than $2 \mathrm{~cm}$ in size ( $\mathrm{p}=0.04$ ). In our opinion, it is important to emphasize the value of early diagnostics and analysis of the malignant tumor characteristics that are major prognostic factors for survival in patients with thyroid cancer.

Key words: thyroid cancer, tumor size, extrathyroidal invasion, multifocality, lymphovascular invasion

\section{Introduction}

Significant changes in the diagnosis and treatment of thyroid disease have occurred over the last three decades. The main reasons for improved diagnostics are better diagnostic testing such as ultrasonography and fine-needle aspiration biopsy ${ }^{1}$. In 2014, thyroid cancer was diagnosed in 606 patients in Croatia, of whom 115 were men and 491 were women, accounting for a rate of $14.3 / 100000^{2}$. The incidence of thyroid cancer

Corresponding author: Stjepan Grga Milankovic, MD, Department of Otorhinolaryngology and Head and Neck Surgery, Osijek Clinical Hospital Centre, J. Huttlera 4, 31000 Osijek, Croatia

E-mail: stjepan.grga.milankovic@gmail.com has rapidly increased in the United States and other developed countries over the past 30 years ${ }^{3}$.

Enlargement of the thyroid gland affects up to $60 \%$ of the population, with higher frequencies in women and the elderly. Most patients with thyroid enlargement can be managed conservatively after the malignancy is ruled out. The challenge to the clinicians is to identify the minority of patients with thyroid cancer who therefore require surgical intervention and additional therapy ${ }^{4}$.

The diagnostic procedure for any newly discovered thyroid nodule should include measurement of serum thyroid-stimulating hormone (TSH) levels. Nonfunctioning nodules will require the use of fine-needle as- 
piration (FNAC) for cytologic evaluation, which is the golden standard for evaluating thyroid nodules 5 . Rout et al. found that diagnostic accuracy of FNAC was $96 \%{ }^{6}$. Thyroid cancer is diagnosed histologically via FNA biopsy and is categorized into 4 main types: well-differentiated (papillary and follicular), medullary, and anaplastic cancer ${ }^{7}$. Papillary thyroid cancer is the most common type of thyroid cancer and accounts for $80-85 \%$ of newly detected malignant thyroid neoplasms. These tumors have an excellent prognosis (25year survival is $95 \%)^{8}$. Many factors influence the long-term outcome of papillary and follicular thyroid cancer, but the patient's age, stage of cancer, and initial treatment are the most important. Stage of cancer is usually based on the size of the primary tumor, extrathyroidal invasion, presence of nodal metastasis, and distant metastatic lesions ${ }^{9}$. Characteristics of thyroid cancer, such as multifocality, are considered as a risk of neck metastases, as are the presence of lymphovascular invasion and tumor size ${ }^{10-12}$. Treatment of differentiated thyroid cancer is the surgical removal of the tumor within the thyroid gland as well as regional lymph nodes. The extent of dissection depends on the involvement of the lymph nodes and includes selective or radical neck dissection ${ }^{13}$.

The aim of this study was to analyze the pathohistological characteristics of malignant thyroid tumors.

\section{Patients and methods}

\section{Patients}

This retrospective study included data from the hospital records of 320 patients who underwent thyroid surgery from January 2018 to December 2019 at the Clinic for Otorhinolaryngology and Head and Neck Surgery in the Osijek Clinical Hospital Centre. The pathohistological diagnosis (PHD) confirmed thyroid cancer in 95 patients. Exclusion criteria were pathohistological diagnosis of a benign tumor or some other thyroid disease. The following data were analyzed: age, gender, fine-needle aspiration biopsy results, and the type of thyroid tumor according to PHD. Characteristics of thyroid cancer such as the size of cancer, lymphovascular invasion, extrathyroidal invasion, and multifocality were also analyzed. According to the American Cancer Society, the size of the cancer was divided into two groups: $<2 \mathrm{~cm}$ and $>2 \mathrm{~cm}$. All data were only available to the researcher, and because this was a retrospective study, the patients did not sign informed consent. This study was approved by the Ethical Committee of our institution.

\section{Statistical analysis}

All data were analyzed using SPSS (IBM Corp. Released in 2013. IBM SPSS Statistics for Windows, Version 21.0. Armonk, NY: IBM Corp.). Differences between categorical variables were tested with the Chi-squared test and Fisher's exact test. Differences in numerical variables between the two independent groups were tested using the Mann-Whitney U test. All $\mathrm{P}$ values were two-sided. The significance level was set at $\alpha=0.05$.

\section{Results}

Out of 320 patients who underwent thyroid surgery, 51 (15.9\%) were men and 269 (84.1\%) were women. Thyroid cancer was diagnosed in 95 patients, of whom 18 (18.9\%) were men and 77 (81.1\%) were women. The median age of patients with thyroid cancer was 53 years (interquartile range, 43-64 years). There was no significant age difference between men and women (Mann-Whitney U test, $\mathrm{p}=0.43$ ) (Table 1). Local neck status was clinically negative in all patients with thyroid cancer.

There was a significant difference between the results of preoperative fine-needle aspiration biopsy and definitive PHD (Chi-squared test, $\mathrm{p}=0.001$ ) (Table 2). According to pathohistological diagnosis, the most common diagnosis was papillary cancer $(75.7 \%)$, and the rarest was medullary cancer (1.1\%). There was a significant difference in the extent of surgery and the final PHD (Chi-squared test, $\mathrm{p}<0.001$ ). The majority of patients with thyroid cancer $(75.8 \%)$ underwent total thyroidectomy. Total thyroidectomy was performed in $80.5 \%$ of patients with papillary cancer, in $71.4 \%$ of patients with micropapillary cancer, and in $80.0 \%$ of patients with papillary cancer with neck metastases. Total thyroidectomy was performed in $40 \%$ of cases with follicular and Hurthle cell cancer and in one case of medullary cancer.

Thyroid cancer was more common in women than in men. There was no significant difference between female and male patients according to the type of thyroid cancer (Chi-squared test, $\mathrm{p}=0.46$ ) (Table 3 ). 
Tumor size was analyzed in 95 patients with thyroid cancer, and it was found that the thyroid cancer was smaller than $2 \mathrm{~cm}$ in 71 patients (74.73\%). There was no significant difference in cancer size regarding the type of thyroid cancer (Chi-squared test, $\mathrm{p}=0.49$ ) (Table 4).

In comparison with male patients, there was a higher incidence of tumors larger than $2 \mathrm{~cm}$ in female patients (83.3\%), but the observed difference was not significant (Fisher's exact test, $\mathrm{p}>0.99$ ).

Multifocality was observed in 21 (22.1\%) patients with thyroid cancer. Eighteen of the patients with multifocality were diagnosed with papillary cancer, one patient had micropapillary cancer, one patient had papillary cancer with neck metastases, and one patient had Hurthle cell cancer. No significant difference was

Table 1. Patient age distribution by sex

\begin{tabular}{|l|l|l|l|}
\hline & $\begin{array}{l}\text { Male } \\
(\mathrm{n}=18)\end{array}$ & $\begin{array}{l}\text { Female } \\
(\mathrm{n}=77)\end{array}$ & $\mathrm{P}^{*}$ \\
\hline $\begin{array}{l}\text { Median (interquartile } \\
\text { range) age (years) }\end{array}$ & $\begin{array}{l}53 \\
(42.8-66.0)\end{array}$ & $\begin{array}{l}53 \\
(41.7-62)\end{array}$ & 0.43 \\
\hline
\end{tabular}

*Mann-Whitney U test found in the presence of multifocality between different types of thyroid cancer (Chi-squared test, $\mathrm{p}=0.80$ ).

There was no significant difference in tumor multifocality between male and female patients (Fisher's exact test, $\mathrm{p}>0.99$ ).

Lymphovascular invasion of thyroid cancer was also studied on 95 patients diagnosed with thyroid cancer. Lymphovascular invasion was present in 20 (21.05\%) patients; 18 of those patients had papillary cancer, one patient had follicular cancer, and one patient had papillary cancer with neck metastases. There was no significant difference in the presence of the lymphovascular invasion between different types of thyroid cancer (Chi-squared test, $\mathrm{p}=0.51$ ).

There was no significant gender difference regarding the lymphovascular invasion of cancer (Fisher's exact test, $\mathrm{p}=0.51$ ).

Extrathyroidal invasion was observed in $95 \mathrm{pa}^{-}$ tients diagnosed with thyroid cancer. It was observed that 14 patients had the extrathyroidal invasion of a certain type of thyroid cancer (12 patients with papillary cancer, one patient with follicular cancer, and one patient with papillary cancer with neck metastases). No significant difference was observed in the presence

Table 2. Results of fine-needle aspiration biopsy compared with definitive pathohistological diagnosis

\begin{tabular}{|c|c|c|c|c|c|c|c|c|}
\hline \multirow[b]{2}{*}{$\begin{array}{l}\text { Fine-needle } \\
\text { aspiration biopsy }\end{array}$} & \multicolumn{6}{|c|}{ Number (\%) of thyroid cancer according to PHD } & \multirow[b]{2}{*}{ Total } & \multirow[b]{2}{*}{$\mathrm{P}^{*}$} \\
\hline & $\begin{array}{l}\text { Papillary } \\
\text { cancer }\end{array}$ & $\begin{array}{l}\text { Micro- } \\
\text { papillary } \\
\text { cancer }\end{array}$ & $\begin{array}{l}\text { Papillary } \\
\text { cancer with } \\
\text { neck metastasis }\end{array}$ & $\begin{array}{l}\text { Follicular } \\
\text { cancer }\end{array}$ & $\begin{array}{l}\text { Hurthle } \\
\text { cell cancer }\end{array}$ & $\begin{array}{l}\text { Medullary } \\
\text { cancer }\end{array}$ & & \\
\hline Papillary cancer & $25(34.7)$ & $0(0)$ & $4(80)$ & $0(0)$ & $0(0)$ & $0(0)$ & $29(30.5)$ & \\
\hline $\begin{array}{l}\text { Lymphocytic } \\
\text { thyroiditis }\end{array}$ & $4(5.6)$ & $0(0)$ & $0(0)$ & $0(0)$ & $0(0)$ & $0(0)$ & $4(4.2)$ & \\
\hline Cyst & $11(15.3)$ & $1(14.3)$ & $0(0)$ & $2(40)$ & $0(0)$ & $0(0)$ & $14(14.7)$ & \\
\hline Insufficient sample & $5(6.9)$ & $1(14.3)$ & $0(0)$ & $0(0)$ & $0(0)$ & $0(0)$ & $6(6.3)$ & \\
\hline $\begin{array}{l}\text { Suspicious papillary } \\
\text { growth }\end{array}$ & $9(12.5)$ & $1(14.3)$ & $1(20)$ & $0(0)$ & $0(0)$ & $0(0)$ & $11(11.6)$ & 0.001 \\
\hline Follicular tumor & $6(8.3)$ & $0(0)$ & $0(0)$ & $0(0)$ & $1(20)$ & $0(0)$ & $7(7.4)$ & \\
\hline Oncocytic tumor & $1(1.4)$ & $1(14.3)$ & $0(0)$ & $2(40)$ & $2(40)$ & $0(0)$ & $6(6.3)$ & \\
\hline Hurthle cell tumor & $2(2.8)$ & $0(0)$ & $0(0)$ & $0(0)$ & $1(20)$ & $0(0)$ & $3(3.1)$ & \\
\hline $\begin{array}{l}\text { Biopsy was not } \\
\text { performed }\end{array}$ & $9(12.5)$ & $2(28.5)$ & $0(0)$ & $1(20)$ & $0(0)$ & $1(100)$ & $13(13.7)$ & \\
\hline Goiter & $0(0)$ & $1(14.3)$ & $0(0)$ & $0(0)$ & $0(0)$ & $0(0)$ & $1(1.1)$ & \\
\hline Medullary cancer & $0(0)$ & $0(0)$ & $0(0)$ & $0(0)$ & $1(20)$ & $0(0)$ & $1(1.1)$ & \\
\hline Total & $72(100)$ & $7(100)$ & $5(100)$ & $5(100)$ & $5(100)$ & $1(100)$ & $95(100)$ & \\
\hline
\end{tabular}

${ }^{*}$ Chi-squared test; PHD: pathohistological diagnosis 
Table 3. Sex distribution according to the type of thyroid cancer

\begin{tabular}{|c|c|c|c|c|c|c|c|c|}
\hline & \multicolumn{6}{|c|}{ Number (\%) of thyroid cancer according to PHD } & \multirow[b]{2}{*}{ Total } & \multirow[b]{2}{*}{$\mathrm{P}^{*}$} \\
\hline & $\begin{array}{l}\text { Papillary } \\
\text { cancer }\end{array}$ & $\begin{array}{l}\text { Micropapillary } \\
\text { cancer }\end{array}$ & $\begin{array}{l}\text { Papillary cancer } \\
\text { with neck metastases }\end{array}$ & $\begin{array}{l}\text { Follicular } \\
\text { cancer }\end{array}$ & $\begin{array}{l}\text { Hurthle } \\
\text { cell cancer }\end{array}$ & $\begin{array}{l}\text { Medullary } \\
\text { cancer }\end{array}$ & & \\
\hline Male & $15(20.8)$ & $0(0)$ & $0(0)$ & $2(40)$ & $1(20)$ & $0(0)$ & $18(18.9)$ & 0.46 \\
\hline Female & $57(79.2)$ & $7(100)$ & $5(100)$ & $3(60)$ & $4(80)$ & $1(100)$ & $77(81.1)$ & \\
\hline Total & $72(100)$ & $7(100)$ & $5(100)$ & $5(100)$ & $5(100)$ & $1(100)$ & $95(100)$ & \\
\hline
\end{tabular}

*Chi-squared test; PHD: pathohistological diagnosis

Table 4. Tumor size in different types of thyroid cancer

\begin{tabular}{|c|c|c|c|c|c|c|c|c|}
\hline & \multicolumn{6}{|c|}{ Number (\%) of thyroid cancer according to PHD } & \multirow[b]{2}{*}{ Total } & \multirow[b]{2}{*}{$\mathrm{P}^{*}$} \\
\hline & $\begin{array}{l}\text { Papillary } \\
\text { cancer }\end{array}$ & $\begin{array}{l}\text { Micropapillary } \\
\text { cancer }\end{array}$ & $\begin{array}{l}\text { Papillary cancer } \\
\text { with neck metastasis }\end{array}$ & $\begin{array}{l}\text { Follicular } \\
\text { cancer }\end{array}$ & $\begin{array}{l}\text { Hurthle } \\
\text { cell cancer }\end{array}$ & $\begin{array}{l}\text { Medullary } \\
\text { cancer }\end{array}$ & & \\
\hline$<2 \mathrm{~cm}$ & $55(76.4)$ & $4(37.1)$ & $3(60)$ & $3(60)$ & $5(100)$ & $1(100)$ & $71(74.7)$ & 0.49 \\
\hline$>2 \mathrm{~cm}$ & $17(23.6)$ & $3(42.9)$ & $2(40)$ & $2(40)$ & $0(0)$ & $0(0)$ & $24(25.3)$ & \\
\hline Total & $72(100)$ & $7(100)$ & $5(100)$ & $5(100)$ & $5(100)$ & $1(100)$ & $95(100)$ & \\
\hline
\end{tabular}

* Chi-squared test; PHD: pathobistological diagnosis

of extrathyroidal invasion between different types of thyroid cancer (Chi-squared test, $\mathrm{p}=0.75$ ).

Extrathyroidal tumor invasion was observed more frequently in female patients, but the difference was not significant in comparison with male patients (Fisher's exact test, $\mathrm{p}=0.70$ ).

There was no significant difference in the presence of multifocality and lymphovascular invasion (Fisher's exact test, $p=0.54$ ), nor in the presence of multifocality and extrathyroidal invasion (Fisher's exact test, $\mathrm{p}=0.50$ ). There were significantly more thyroid cancers with lymphovascular invasion that did not have extrathyroidal invasion (Fisher's exact test, $\mathrm{p}=0.001$ ). There was no significant difference in the presence of extrathyroidal invasion and multifocality regarding the tumor size (Fisher's exact test, $p>0.99$; Fisher's exact test, $\mathrm{p}=0.57$ ), but there were significantly more cancers with lymphovascular invasion that were less than $2 \mathrm{~cm}$ in size (Fisher's exact test, $\mathrm{p}=0.04$ ).

\section{Discussion}

In this study, we investigated the characteristics of malignant thyroid tumors, such as tumor size, multifocality, and lymphovascular and extrathyroidal invasion of the tumor. We also investigated the difference between fine-needle aspiration biopsy and PHD based on the data pool at the Department of Otorhinolaryn- gology and Head and Neck Surgery, Osijek Clinical Hospital Centre.

Our study showed that there was a significant difference between the results of fine-needle aspiration biopsy and PHD, which emphasizes the importance of pathohistological diagnosis in determining malignancy in suspicious thyroid tissue lesions. In 2018, Machala et al. reported that even though fine-needle aspiration biopsy is a very important screening procedure for thyroid tumors with an accuracy of $89.46 \%$, every thyroid lesion requires adequate pathological interpretation. One of the crucial problems regarding fine-needle aspiration biopsy is papillary microcarcinoma, which is hard to detect with this method. Furthermore, lesions like goiter and follicular adenoma are very hard to differentiate from follicular cancer using only fineneedle aspiration biopsy ${ }^{14}$. However, fine needle aspiration biopsy correlates with histopathology diagnoses in about $30 \%$ of the cases in our study. This could be due to the increased number of fine needle aspiration biopsies as a result of higher number of thyroid nodules found by ultrasonography examination. Furthermore, some of the diagnostic features of papillary cancer, the most prevalent cancer in our study, can be present even in benign changes of thyroid gland ${ }^{15}$, which could also explain this discrepancy.

By analyzing PHD, we found that malignant tumors had been detected in 95 patients, but mostly in 
women, which is in line with data from the literature on the higher incidence of thyroid cancer in women ${ }^{8}$. Durante et al. reported that around 10\% of thyroid nodules can carry clinically notable cancer. However, most of the thyroid nodules tend to be asymptomatic with very small malignancy potential and usually require thorough patient follow-up ${ }^{16}$. It is also important to emphasize that Bartolotta et al. reported that multiple thyroid nodules had been found more often in female subjects (58.5\%) in comparison with male subjects $(41.5 \%)$ and that the number of thyroid nodules increases with age ${ }^{17}$.

By examining our research data, we found that papillary cancer was the most common diagnosis according to PHD, which is consistent with data from the literature ${ }^{18-20}$.

Twenty-four patients $(25.26 \% ; 4$ men and 20 women) in our study were diagnosed with thyroid cancer larger than $2 \mathrm{~cm}$; 17 of those patients were diagnosed with papillary thyroid cancer. The higher incidence of cancer larger than $2 \mathrm{~cm}$ in women can certainly be explained by the higher number of female patients with thyroid cancer in our study, but also by the influence of estrogen. Estrogen is a potential growth factor for malignant thyroid cancer cells, which affects the higher prevalence of thyroid cancer in women as well as the presence of larger tumors ${ }^{21}$. However, there was no significant difference in cancer size regarding the type of thyroid cancer and gender. In 2005, Machens et al. conducted a retrospective study and concluded that there is a cumulative risk of distant metastases from papillary and follicular thyroid tumors with a size of $2 \mathrm{~cm}$ or more ${ }^{22}$. However, a recent study by Nguyen et al. showed that at a size of $<2.5 \mathrm{~cm}$, there is $<5 \%$ probability for papillary thyroid tumor local invasion and a $<1 \%$ probability for follicular thyroid tumor local invasion ${ }^{23}$.

According to our results, we can see that, with regard to the final PHD, total thyroidectomies were mostly performed in patients with papillary and $\mathrm{mi}^{-}$ cropapillary cancer as well as in patients with papillary carcinoma with neck metastases, which is in line with the result that FNS biopsy findings and final PHD correlate the most in these types of cancers.

In 2015, Al Afif et al. reported that multifocality had been observed in $63 \%$ of the patients with papillary thyroid carcinoma included in their study and that there was a higher chance of level VI lymph node me- tastases depending on tumor foci number ${ }^{11}$. According to our results, the prevalence of multifocality in thyroid cancer is lower, and it was present in 21 patients (22.1\%; 3 men and 18 women), with papillary cancer as the most common diagnosis (18 cases). The presence of level VI lymph node metastases doubled if there were 3-9 foci present, and it even quadrupled if there were more than 10 foci present ${ }^{11}$. Furthermore, Chen et al. and Lu et al. concluded that multifocality is related to a higher probability of disease recurrence and bad prognosis in comparison with unifocal thyroid carcinoma ${ }^{24,25}$. Tumor multifocality, especially regarding papillary thyroid cancer, is a characteristic that shows tumor aggressiveness.

Extrathyroidal invasion is considered to be highly associated with poor outcome in patients with thyroid cancer. It was present in 14 patients $(14.73 \%$; 3 men and 11 women) in our study and for the most part in papillary cancer, but without a significant difference in incidence with respect to other types of thyroid cancer. According to Youngwirth et al., patients without extrathyroidal invasion had improved 5-year survival (96\%) when compared with patients with confirmed extrathyroidal extension, either minimal (94\%) or extensive extension $(88 \%)^{26}$. Moreover, Radowsky et al. showed that there is a higher possibility of clinical recurrence of the disease due to extrathyroidal extension of papillary thyroid cancer ${ }^{27}$.

Apart from characteristics such as multifocality and extrathyroidal invasion, a lymphovascular invasion is a very important characteristic in correlation with the patient's outcome. In this study, we found that lymphovascular invasion had been present in $20 \mathrm{pa}-$ tients (21.05\%; 2 men and 18 women). There were 18 of 20 patients with the lymphovascular invasion, with the highest incidence in papillary cancer. In 2017, Sezer et al. found that lymphovascular invasion was present in $9.3 \%$ of patients out of total 705 patients from the study. Furthermore, the presence of lymphovascular invasion in patients with papillary thyroid carcinoma could be associated with disease progres$\operatorname{sion}^{12}$. In contrast to our results, Pontius et al. conducted a study in 2016 on 45415 patients with thyroid cancer and found that $11.6 \%$ of those patients had also had lymphovascular invasion of the cancer. In addition, they found that lymphovascular invasion was associated with some of the thyroid tumor characteristics such as multifocality, extrathyroidal extension, and distant metastases $^{28}$. 
Thyroid cancers that had lymphovascular invasion were significantly more often without extrathyroidal invasion and less than $2 \mathrm{~cm}$ in size, which is in contrast to the results of the study by Sezer et al. in which the risk of lymphovascular invasion was higher if the tumor was larger ${ }^{12}$.

The limitations of this study are the smaller number of patients compared with other studies and the retrospective structure of the study.

In conclusion, although FNA biopsy does not correlate with final PHD in even half of patients with thyroid cancer, it is important to emphasize the importance of early diagnostics and analysis of malignant tumors characteristics that are the major prognostic factor for survival. With the help of ultrasound diagnostics and cytology analysis of malignant thyroid disease, we expect malignant thyroid tumor treatment and patient follow-up to be even more efficient. Regardless of the type of thyroid cancer, we can also expect that negative prognostic factors such as multifocality, lymphovascular and extrathyroidal invasion, and tumor size less than $2 \mathrm{~cm}$ do not indicated the presence of more favorable prognostic factors.

\section{Conflict of interest:}

The authors declare that there is no conflict of interest.

\section{References}

1. Prpić M, Franceschi M, Romić M, Jukić T, Kusić Z. Thyroglobulin as a Tumor Marker in Differentiated Thyroid Cancer - Clinical Considerations. Acta Clin Croat. 2018 Sep;57(3): 518-527. doi: 10.20471/acc.2018.57.03.16

2. Kusić Z, Prgomet D. Karcinom štitne i doštitne žljezde. In: Prgomet D, editor. Tumori glave i vrata. Zagreb: Medicinska naklada; 2019.p. 262-73. Croatian.

3. Olson E, Wintheiser G, Wolfe KM, Droessler J, Silberstein PT. Epidemiology of Thyroid Cancer: A Review of the National Cancer Database, 2000-2013. Cureus. 2019 Feb 24;11 (2):e4127. doi: 10.7759/cureus.4127

4. Watkinson J, Gilbert R, Stell P, Maran A. Stell and Maran's textbook of head and neck surgery and oncology. 5th ed. London: Hodder Arnold; 2012.

5. Haugen BR, Alexander EK, Bible KC, Doherty GM, Mandel SJ, Nikiforov YE, et al. 2015 American Thyroid Association Management Guidelines for Adult Patients with Thyroid Nodules and Differentiated Thyroid Cancer: The American Thyroid Association Guidelines Task Force on Thyroid Nodules and Differentiated Thyroid Cancer. Thyroid. 2016 Jan;26(1):1-133. doi: 10.1089/thy.2015.0020
6. Rout K, Ray CS, Behera SK, Biswal R. A Comparative Study of FNAC and Histopathology of Thyroid Swellings. Indian J Otolaryngol Head Neck Surg. 2011 Oct;63(4):370-2. doi: 10.1007/s12070-011-0280-0

7. Tacalliti A, Boscaro M. Genetic mutations in thyroid carcinoma. Minerva endocrinologica. 2009 Apr;34(1):11-28.

8. Bumber B, Marjanovic Kavanagh M, Jakovcevic A, Sincic N, Prstacic R, Prgomet D. Role of matrix metalloproteinases and their inhibitors in the development of cervical metastases in papillary thyroid cancer. Clinical Otolaryngology. 2020 Jan; 45(1):55-62. doi: 10.1111/coa.13466

9. Mazzaferri EL. Long-term outcome of patients with differentiated thyroid carcinoma: effect of therapy. Endocr Pract. 2000 Nov-Dec;6:469-76. doi: 10.4158/EP.6.6.469

10. Han K, Kim E, Kwak J. 1.5-2 cm tumor size was not associated with distant metastasis and mortality in small thyroid cancer: A population-based study. Sci Rep. 2017 Apr;7:46298. doi.org/ 10.1038/srep46298

11. Al Afif A, Williams BA, Rigby MH, Bullock MJ, Taylor SM, Trites J, et al. Multifocal Papillary Thyroid Cancer Increases the Risk of Central Lymph Node Metastasis. Thyroid. 2015 Sep; 25(9):1008-12. doi: 10.1089/thy.2015.0130

12. Sezer A, Celik M, Bulbul BY, Can N, Tastekin E, Ayturk S, et al. Relationship between lymphovascular invasion and clinicopathological features of papillary thyroid carcinoma. Bosn J Basic Med Sci. 2017 May;17(2): 144-51. doi: 10.17305/ bjbms.2017.1924

13. Prgomet D, Bilić M, Kovac L, Hutinec Z, Topić I. Locally invasive papillary thyroid cancer--our experience. Lijec Vjesn. 2012 Sep-Oct;134(9-10):266-70.

14. Machała E, Sopiński J, Javorska J, Kołomecki K. Correlation of Fine Needle Aspiration Cytology of Thyroid Gland with Histopathological Results. Pol Przegl Chir. 2018 Aug 21;90(6): 13-19. doi: 10.5604/01.3001.0012.4712

15. Sharma C. Diagnostic accuracy of fine needle aspiration cytology of thyroid and evaluation of discordant cases. J Egypt Natl Canc Inst. 2015 Sep;27(3):147-53. doi: 10.1016/j.jnci.2015. 06.001

16. Durante C, Grani G, Lamartina L, Filetti S, Mandel SJ, Cooper DS. The Diagnosis and Management of Thyroid Nodules. JAMA. 2018 Mar 6;319(9):914-24. doi:10.1001/jama. 2018.0898

17. Bartolotta TV, Midiri M, Runza G. Incidentally discovered thyroid nodules: incidence, and greyscale and colour Doppler pattern in an adult population screened by real-time compound spatial sonography. Radiol med. 2006 Oct;111(7): 989-98. doi: 10.1007/s11547-006-0097-1

18. Hrnčić N, Goga A, Hrnčić S, Filipovska-Mušanović $M$, Hatibović H, Hodžić Đ. Frequency of thyroid cancer in patients operated at Cantonal Hospital Zenica, Bosnia and Herzegovina, in the period 2007- 2014. Med Glas (Zenica). 2016 Aug 1;13(2):113-7. doi: 10.17392/846-16

19. Hundahl SA, Fleming ID, Fremgen AM, Menck HR. A National Cancer Data Base report on 53,856 cases of thyroid car- 
cinoma treated in the U.S., 1985-1995. Cancer. 1998 Dec 15; 83(12):2638-48. doi: 10.1002/(sici)1097-0142(19981215)83: $12<2638$ ::aid-cncr31>3.0.co;2-1

20. American Thyroid Association (ATA) Guidelines Taskforce on Thyroid Nodules and Differentiated Thyroid Cancer, Cooper DS, Doherty GM, Haugen BR, Kloos RT, Lee SL, et al. Revised American Thyroid Association management guidelines for patients with thyroid nodules and differentiated thyroid cancer. Thyroid. 2009 Nov;19 (11):1167-214. doi: 10.1089/ thy.2009.0110

21. Derwahl M, Nicula D. Estrogen and its role in thyroid cancer. Endocr Relat Cancer. 2014 Oct;21(5):T273-83. doi: 10.1530/ ERC-14-0053

22. Machens A, Holzhausen HJ, Dralle H. The prognostic value of primary tumor size in papillary and follicular thyroid carcinoma. Cancer. 2005 Jun 1;103(11):2269-73. doi: 10.1002/ cncr. 21055

23. Nguyen XV, Roy Choudhury K, Tessler FN, Hoang JK. Effect of Tumor Size on Risk of Metastatic Disease and Survival for Thyroid Cancer: Implications for Biopsy Guidelines. Thyroid. 2018 Mar;28(3):295-300. doi: 10.1089/thy.2017.0526
24. Chen Q, Zou XH, Wei T, Huang QS, Sun YH, Zhu JQ. Prediction of ipsilateral and contralateral central lymph node metastasis in unilateral papillary thyroid carcinoma: a retrospective study. Gland Surg. 2015 Aug;4(4):288-94. doi: 10.3978/j. issn.2227-684X.2015.05.06

25. Lu Y, Lin J, Chao C, Haitao C, Qinghua Y. Clinicopathologic characteristics and outcomes of papillary thyroid carcinoma in younger patients. Medicine. 2020 Apr 10;99(15): e19795. doi: 10.1097/MD.0000000000019795

26. Youngwirth LM, Adam MA, Scheri RP, Roman SA, Sosa JA. Extrathyroidal Extension Is Associated with Compromised Survival in Patients with Thyroid Cancer. Thyroid. 2017 May;27(5):626-31. doi: 10.1089/thy.2016.0132

27. Radowsky JS, Howard RS, Burch HB, Stojadinovic A. Impact of degree of extrathyroidal extension of disease on papillary thyroid cancer outcome. Thyroid. 2014 Feb;24(2):241- 4. doi: 10.1089/thy.2012.0567

28. Pontius LN, Youngwirth LM, Thomas SM, Scheri RP, Roman SA, Sosa JA. Lymphovascular invasion is associated with survival for papillary thyroid cancer. Endocr Relat Cancer. 2016 Jul;23(7):555-62. doi: 10.1530/ERC-16-0123

Sažetak

\title{
KARAKTERISTIKE ZLOĆUDNIH TUMORA ŠTITNJAČE: RETROSPEKTIVNA STUDIJA NA 320 PACIJENATA
}

\author{
I. Abičic, T. Prpiç, V. Bogović, S. Grga Milanković, H. Mihalj, A. Vceva, Ž. Zubčic, A. Šestak i M. Rezo
}

Papilarni karcinom štitnjače čini 80-85\% dijagnosticiranih karcinoma štitnjače, dok su folikularni, medularni i anaplastični značajno manje zastupljeni. Cilj studije je bio analizirati patohistološke karakteristike malignih tumora štitnjače. U ovoj retrospektivnoj studiji, analizirani su podaci od 320 pacijenata koji su operirali štitnjaču u razdoblju od siječnja 2018. godine do prosinca 2019. godine. Zabilježeni su i statistički obrađeni osnovni demografski podaci, podatak o citološkom i patohistološkom nalazu, te karakteristike tumora (veličina, multifokalnost, ekstratireoidna i limfovaskularna invazija). Karcinom štitnjače je potvrđen kod 95 pacijenata. Veća je učestalost karcinoma štitnjače kod žena u odnosu na muškarce, ali bez značajne razlike $(p=0.46)$. Zabilježena je značajna razlika između preoperativnog nalaza citološke punkcije i definitivnog patohistološkog nalaza ( $\mathrm{p}=0.001)$. Nije bilo značajne razlike u veličini tumora, ekstratireoidnoj i limfovaskularnoj invaziji, multifokalnosti u odnosu na spol. Značajno je više bilo karcinoma koji su imali prisutnu limfovaskularnu invaziju s veličinom manjom od $2 \mathrm{~cm}(\mathrm{p}=0.04)$. Prema rezultatima studije, bitno je naglasiti važnost rane dijagnostike te analizu karakteristika malignih tumora štitnjače koji su važan prognostički faktor preživljenja kod pacijenata s karcinomom štitnjače.

Ključne riječi: karcinom štitnjače, veličina tumora, ekstratireoidna invazija, multifokalnost, limfovaskularna invazija. 